\title{
Predictors of Intra-Hospital Mortality in Patients with Cirrhosis
}

\author{
Iliass Charif1,2*, Kaoutar Saada',2, Ihssane Mellouki1,2, Mounia El Yousfi',2, \\ Dafrallah Benajah",2, Mohamed El Abkari'1,2, Adil Ibrahimii,2, Nourdin Aqodadi,2 \\ ${ }^{1}$ Department of Gastroenterology and Hepatology, Hassan II University Hospital, Fez, Morocco \\ ${ }^{2}$ Faculty of Medicine and Pharmacy of Fez, Sidi Mohammed Ben Abdellah University of Fez, Fez, Morocco \\ Email: charifiliass82@hotmail.com
}

Received 12 January 2014; revised 16 February 2014; accepted 24 February 2014

Copyright (C) 2014 by authors and Scientific Research Publishing Inc.

This work is licensed under the Creative Commons Attribution International License (CC BY). http://creativecommons.org/licenses/by/4.0/

(c) (i) Open Access

\begin{abstract}
Intra-hospital mortality in cirrhotic patients is variable depending on the studies reported in literature. Several studies have demonstrated independent predictors of mortality. The aim of this work is indeed to identify these predictors. Patients and Methods: We conducted a retrospective study of 1080 cirrhotic patients hospitalized in our department of gastroenterology and hepatology between January 2001 and August 2010. A descriptive study of the study population was performed, and a univariate analysis looking for an association between intra-hospital mortality, and clinical, biological, etiological and socio-demographic characteristics of our patients. Results: The average age of our patients was 54 years, with an equal number of men and women. $41.1 \%$ of patients had cirrhosis secondary to hepatitis $C$ and $18.5 \%$ had cirrhosis secondary to hepatitis $B$. $26.1 \%$ of our patients were CHILD C. Intra-hospital mortality was $8.7 \%$ (97 deaths) with a mean of $23.4 \pm 35.8$ months. Univariate analysis showed that the intra-hospital mortality was significantly associated with higher age $(p=0.049)$ as well as the reasons for admissions like hepatic encephalopathy, and hematemesis ( $<$ 0.0001), melena, jaundice and ascites $(p=0.001)$. Among the biological parameters analyzed in univariate analysis, significant associations with mortality were objectified for high white blood cell count $(p=0.035)$, and high serum bilirubin and creatinine ( $p$ $<0.0001)$; low rate of prothrombin time $(P T)(p<0.0001)$, of albumin $(p=0.0001)$ and of serum sodium $(p<0.0001)$. Among the complications analyzed, significant associations with mortality were objectified for jaundice, ascites $(p=0.001)$, hemorrhagic decompensation, hepatic encephalopathy, and spontaneous bacterial peritonitis $(p<0.001)$. Univariate analysis of the etiology of cirrhosis objectified significant associations for cirrhosis secondary to hepatitis $B(p=0.001)$ and hepatitis $C(p=0.022)$. Multivariate analysis objectified four independent predictors of mortality: hepatic encephalopathy, infection (hyper leukocytosis $\geq 10,000 / \mathrm{mm}^{3}$ ), renal failure (serum creatinine $\geq 15 \mathrm{mg} / \mathrm{l}$ ) and hyponatremia. Conclusion: In our series, we identified four independent predictors of intra-hospital mortality in cirrhotic patients: hepatic encephalopathy, infection, renal failure and hyponatremia.
\end{abstract}

*Corresponding author. 


\section{Keywords}

\section{Cirrhosis; Portal Hypertension; Intra-Hospital Mortality}

\section{Introduction}

The search for risk factors that stratify cirrhotic patients into subgroups with different survival rates is of great prognostic value for the clinician. Many studies have focused on the search for predictors of mortality in cirrhotic patients, and their use to develop a reliable model of survival. In these studies, the study populations were cirrhotic patients [1]-[5], patients with alcoholic cirrhosis [6] [7], and cirrhotic patients after an episode of variceal bleeding [8]-[12]. The Child-Turcott score [1] and its subsequent modifications by Pugh [8] are old empirical methods used to assess the degree of liver failure in candidate patients for porto-systemic shunt. Although the statistical accuracy of the Child-Pugh score (CPS) was not assessed, it was long considered to be an adequate method to determine the degree of liver failure, and the probability of survival [13]-[15]. However, two of its elements are very subjective (ascites and encephalopathy) [5]. In some studies, the prognostic value of CPS has been described as incomplete. In addition, several other clinical and biological variables not included in the CPS were demonstrated to have prognostic significance [16]. In our study, the principal etiology of cirrhosis in our patients is hepatitis B and C. It seemed, therefore, interesting to investigate the factors involved in the short-term survival in these cirrhotic patients.

\section{Patients and Methods}

- Study population

We present a retrospective study of cirrhotic patients admitted in our department of hepatology and gastroenterology at the University Hospital of Fez, between January 2001 and January 2010. The diagnosis of cirrhosis was based on the combination of clinical, biological, endoscopic and ultra-sonographic criteria.

- Variables studied

All patients had received a biological assessment within 24 hours of admission. The variables studied were: age, sex, presence of ascites, encephalopathy, presence of hemorrhage, jaundice, hepatocellular carcinoma (HCC), platelet count, white blood cells, transaminases, prothrombin time, bilirubin, albumin, creatinine, serum sodium, spontaneous bacterial peritonitis, the etiology of cirrhosis and CPS.

- Statistical Methods

A descriptive study of our population was conducted, as well as univariate and multivariate analysis looking for an association between mortality and clinical, biological and socio-demographic characteristics of our patients. We used standard descriptive statistics to characterize the population studied: mean, standard deviation, median, range. Comparison of two independent variables with normal distribution was performed using the Student test (t) whereas comparisons of more than two means were based on analysis of variance (ANOVA). A multivariate analysis was performed using a technique of logistic regression stepwise including all variables and significance level was defined as a value less than 0.2 in univariate analysis. In all statistical tests, the risk of error $\alpha$ was set at 0.05 . Data were analyzed using Epi Info ${ }^{\mathrm{TM}}$ 3.5.1 software.

\section{Results}

Between January 2001 and January 2010, 1080 patients were included in this study. The clinical characteristics of patients are shown in Table 1. The average age was 54 years, sex ratio M/F was 1.05 with 555 (51.3\%) men and $525(48.6 \%)$ women. Ninety-six percent $(\mathrm{N}=746)$ of patients had ascites, 46.5\% $(\mathrm{N}=503)$ had a hemorrhagic decompensation and $12.3 \%(\mathrm{~N}=12.3)$ had hepatic encephalopathy. Forty-two percent $(\mathrm{N}=463)$ of patients had cirrhosissecondary to hepatitis Cand $19.9 \%(\mathrm{~N}=215)$ secondary to hepatitis $\mathrm{B}$. Twenty-six percent of patients were Child C, and 7\% $(\mathrm{N}=75)$ had a HCC.

The hospital mortality was $8.7 \%$ (97 deaths).

In univariate analysis, factors associated with intra-hospital mortality in cirrhotic patients (Tables 2 and 3) were older age $(p=0.049)$, and reasons for admission: hepatic encephalopathy and hematemesis $(p<0.0001)$, 
Table 1. General data of patients $(\mathrm{N}=1080)$.

\begin{tabular}{cc}
\hline Mean age & 54 ans \\
Men & $555(51.3 \%)$ \\
women & $525(48.6 \%)$ \\
Ascites & $746(96 \%)$ \\
Variceal bleeding & $503(46.5 \%)$ \\
Hepatic encephalopathy & $133(12.3 \%)$ \\
Cirrhosis secondary to hepatitis & \\
C & $463(42.8 \%)$ \\
B & $215(19.9 \%)$ \\
CHILD & \\
A & $19.2 \%$ \\
B & $54.6 \%$ \\
C & $26.1 \%$ \\
HCC & $75(6.9 \%)$ \\
\hline
\end{tabular}

Table 2. Comparison of sex and age between patients who died and survivors.

\begin{tabular}{cccc}
\hline & Survivors $(\mathrm{n}=984)$ & Deads $(\mathrm{n}=96)$ & $\mathrm{p}$ \\
\hline Sex ratio $(\mathrm{M} / \mathrm{F})$ & 0.9 & 1.2 & 0.178 \\
Age & $52.2 \pm 17.17$ & $55.8 \pm 14.39$ & 0.049 \\
\hline
\end{tabular}

Table 3. Comparison of reasons for hospitalization among patients who died and survivors.

\begin{tabular}{cccc}
\hline & Survivors $(\mathrm{n}=984)$ & Deads $(\mathrm{n}=96)$ & $\mathrm{p}$ \\
\hline Asthenia & $17.1 \%$ & $18.8 \%$ & 0.678 \\
Fever & $12.3 \%$ & $16.7 \%$ & 0.219 \\
Hematemesis & $38.0 \%$ & $59.4 \%$ & 0.0001 \\
Melena & $27.2 \%$ & $42.7 \%$ & 0.001 \\
Jaundice & $20.6 \%$ & $35.4 \%$ & 0.001 \\
Ascites & $53.7 \%$ & $71.9 \%$ & 0.001 \\
Edema of the lower limbs & $17.3 \%$ & $21.9 \%$ & 0.260 \\
Hepatic encephalopathy & $6.4 \%$ & $21.9 \%$ & $<0.0001$ \\
\hline
\end{tabular}

melena, jaundice and ascites $(\mathrm{p}=0.001)$. Among the biological parameters (Table 4), significant associations with mortality were objectified for high levels of white blood cell count $(p=0.035)$, of serum bilirubin ( $<<$ 0.0001), and of serum creatinine ( $<0.0001)$; low rates of PT $(\mathrm{p}<0.0001)$, of albumin $(\mathrm{p}=0.000)$ and of serum sodium ( $\mathrm{p}<0.0001)$. Complications of cirrhosis were analyzed also in univariate analysis (Table 5), and significant associations with mortality were objectified for jaundice, ascites $(p=0.001)$, hemorrhagic decompensation, hepatic encephalopathy and spontaneous bacterial peritonitis $(\mathrm{p}<0.0001)$. Concerning the etiology of cirrhosis (Table 6) significant associations with mortality were found forcirrhosis secondary to hepatitis B $(p=0.001)$ and hepatitis $C(p=0.022)$. The multivariate analysis (Table 7) has objectified four independent predictors of mortality, which are hepatic encephalopathy $(\mathrm{OR}=14.9)$, infection (leukocytosis $\left.\geq 10,000 / \mathrm{mm}^{3}\right)(\mathrm{OR}=6.9)$, renal failure (Creatinine $\geq 15 \mathrm{mg} / \mathrm{l})(\mathrm{OR}=10.8)$ and hyponatremia $(\mathrm{OR}=15.3)$.

\section{Discussion}

In our series, the intra-hospital mortality was $8.7 \%$, a figure much lower than the literature data. However, the 
Table 4. Comparison of biological parameters between patients who died and survivors.

\begin{tabular}{cccccc} 
& \multicolumn{2}{c}{ Survivors } & \multicolumn{2}{c}{ Deads } & $\mathrm{p}$ \\
\cline { 2 - 4 } & $\mathrm{n}$ & Average $\pm \mathrm{SD}$ & $\mathrm{N}$ & Average $\pm \mathrm{SD}$ & \\
\hline $\mathrm{Hb}(\mathrm{g} / \mathrm{l})$ & 865 & $9.6 \pm 3.05$ & 87 & $9.1 \pm 3.16$ & 0.126 \\
$\mathrm{~GB}\left(10^{3} / \mathrm{mm}^{3}\right)$ & 918 & $6.2 \pm 11.61$ & 90 & $8.8 \pm 5.43$ & 0.35 \\
Platelets $\left(10^{3} / \mathrm{mm}^{3}\right)$ & 867 & $129.3 \pm 99.92$ & 85 & $133.8 \pm 83.31$ & 0.689 \\
PT (\%) & 912 & $69 \pm 20.93$ & 81 & $56.1 \pm 23.47$ & $<0.0001$ \\
Albumine (g/l) & 168 & $31.8 \pm 7.55$ & 17 & $24.5 \pm 5.5$ & 0.000 \\
Bilirubin (mg/l) & 541 & $26.6 \pm 43.73$ & 56 & $58.9 \pm 70,79$ & $<0.0001$ \\
Creatinine (mg/l) & 740 & $9.3 \pm 7.39$ & 72 & $14.6 \pm 11.91$ & $<0.0001$ \\
Natremia (meq/l) & 525 & $136.3 \pm 5.74$ & 58 & $131.5 \pm 9.02$ & $<0.0001$ \\
\hline
\end{tabular}

Table 5. Comparison of the occurrence of complications of cirrhosis between patients who died and survivors.

\begin{tabular}{cccc}
\hline & Survivors $(\mathrm{n}=984)$ & Deads $(\mathrm{n}=96)$ & $\mathrm{p}$ \\
\hline Variceal bleeding & $44.8 \%$ & $66.6 \%$ & $<0.0001$ \\
Ascites & $67.7 \%$ & $84.3 \%$ & 0.001 \\
Hepatic encephalopathy & $10.1 \%$ & $36.4 \%$ & $<0.0001$ \\
SBP & $3.3 \%$ & $12.5 \%$ & $<0.0001$ \\
Jaundice & $20.6 \%$ & $35.4 \%$ & 0.001 \\
HCC & $6.9 \%$ & $9.3 \%$ & 0.370 \\
\hline
\end{tabular}

SBP: spontaneous bacterial peritonitis, HCC: Hepatocellular carcinoma.

Table 6. Comparison of etiology of cirrhosis between patients who died and survivors.

\begin{tabular}{cccc}
\hline & Survivors $(\mathrm{n}=984)$ & Deads $(\mathrm{n}=96)$ & $\mathrm{p}$ \\
\hline Cirrhosis secondary to hepatitis C & $41.4 \%$ & $58.7 \%$ & 0.022 \\
Cirrhosis secondary to hepatitis B & $17.8 \%$ & $42.2 \%$ & 0.001 \\
Alcoholic cirrhosis & $2.1 \%$ & $3.1 \%$ & 0.530 \\
\hline
\end{tabular}

Table 7. Multivariate analysis of in-hospital mortality in cirrhotic.

\begin{tabular}{|c|c|c|}
\hline & OR (IC 95\%) & $\mathrm{p}$ \\
\hline $\begin{array}{l}\text { Leucocytes } \\
<10,000 / \mathrm{mm}^{3} \\
>10,000 / \mathrm{mm}^{3}\end{array}$ & $\begin{array}{c}1 \\
6.9(1.39-34.07)\end{array}$ & 0.018 \\
\hline $\begin{array}{l}\text { Creatinine } \\
<15 \mathrm{mg} / \mathrm{l} \\
>15 \mathrm{mg} / \mathrm{l}\end{array}$ & $\begin{array}{c}1 \\
10.8(1.9-59.49)\end{array}$ & 0.006 \\
\hline $\begin{array}{l}\text { Natremia } \\
>130 \mathrm{meq} / \mathrm{l} \\
>130 \mathrm{meq} / \mathrm{l}\end{array}$ & $\begin{array}{c}1 \\
15.3(3.13-74.93)\end{array}$ & 0.001 \\
\hline $\begin{array}{c}\text { Hepatic encephalopathy } \\
\text { Absent } \\
\text { Present }\end{array}$ & $\begin{array}{c}1 \\
14.9(2.20-101.16)\end{array}$ & 0.006 \\
\hline
\end{tabular}


medical structures of admission of cirrhotic patients with complications are variable, making it difficult to compare mortality figures observed. It may be a hepatology and gastroenterology service or intensive care units [17].

Several studies had studied prognostic factors in patients with cirrhosis, and elaborated a survival models, easy to use in routine practice.

According to the findings of the international consensus conference of Baveno IV [18], there is no adequate prognostic model of portal hypertension in patients with cirrhosis, and individual characteristics are insufficient to establish a prognosis. However, four clinical stages of portal hypertension, of increasing severity were identified.

In addition, the CPS, active bleeding at endoscopy, the portosystemic pressure gradient, infection, renal failure, the severity of the initial bleeding episode, vein thrombosis and HCC were identified as indicators of poor prognosis [19] [20].

The older age was significantly associated with mortality in our series, this was also reported in the series of Luca. A et al. [21], in contrast to several studies that have not objectified significant association between age and mortality [22] [23].

The circumstances of admission of cirrhotic patients with complications in intensive care units such as gastrointestinal bleeding, sepsis, impaired consciousness associated with encephalopathy, acute respiratory distress syndrome or acute renal failure have been associated with high mortality in these patients [24]. In our study, variceal bleeding, jaundice, ascites and hepatic encephalopathy were significantly associated with mortality, which was similar to the literature data [24].

Gastrointestinal bleeding due to rupture of esophageal varices is the second leading cause of cirrhosis mortality [25]. Twenty to $40 \%$ of deaths occur in the following year of the bleeding episode and the mortality rate is $15 \%$ to $30 \%$ at 6 weeks [26] and 50\% in patients with Child C [27]. The severity of variceal bleeding cannot be dissociated from the severity of cirrhosis that is appreciated by the degree of liver failure. The bleeding episode may worsen liver function and the underlying liver disease. The death is not related to hemorrhage itself (initial blood loss), because there is rarely an acute and massive hypovolemia, but due to complications such as infections, hepatic encephalopathy, severity of liver failure and kidney failure. Survival after bleeding episode has improved in 40 years, going from $45 \%$ to $60 \%$. This result was due to a rapid assessment of the gravity (identified prognostic factors), non-specific intensive care, and the early introduction of a specific medical treatment of variceal bleeding (vasoactive drogues) [28] [29]. In our series, hemorrhagic decompensation was significantly associated with mortality in univariate analysis.

Several parameters were associated with intra-hospital mortality in cirrhotic patients, the most important being the degree of liver failure, since the bilirubin and prothrombin time were associated with a greater risk of mortality in several studies [30]. In our study, a prothrombin time $<45 \%$, serum bilirubin $>50 \mathrm{mg} / \mathrm{l}$, and serum albumin $<28 \mathrm{~g} / \mathrm{l}$ were significantly associated with mortality, confirming the data of literature.

The prospective study of Singh and al shows that liver failure assessed by CPS and the model for end stage liver disease (MELD) are the main prognostic factor for short-term survival and the occurrence of complications [31].

Other factors of severity seem to be independent prognostic factors; these factors are active bleeding, renal function, a massive transfusion of more than 5 red blood cells, an initial state of shock and tracheal intubation [32].

In our study, we found that kidney failure was a poor prognostic factor in patients with cirrhosis, and serum creatinine at admission was higher in cirrhotic patients who died than in survivors, findings that are consistent with previous studies [33].

According to some studies, hyponatremia is associated with higher mortality [22]. In our series, serum sodium $\leq 130 \mathrm{meq} / \mathrm{l}$ was a poor prognostic factor in these patients. We also identified leukocytosis $>10,000 / \mathrm{mm}^{3}$ as a poor prognostic factor and this leukocytosis is usually incorporated in severe sepsis. In a meta-analysis [34], the occurrence of infection was associated with recurrent bleeding and a higher mortality.

The etiology of cirrhosis does not appear to be independent prognostic factors [33]. In our study, the viral origin of cirrhosis emerged as a predictor of mortality, which confirms its more virulent and aggressive character than other liver diseases.

Ascites occurs in $30 \%$ of patients with cirrhosis. The occurrence of ascites is a major event in the natural history of cirrhosis, and survival rates at 1 and 5 years, are respectively $50 \%$ and $20 \%$. Ten percent of patients develop refractory ascites which is a reflection of severe liver failure. The survival of these patients is $40 \%$ to $60 \%$ 
at 1 year and $20 \%$ - $40 \%$ at 2 years [35]. In our series, ascites was also associated with a high mortality in cirrhotic patients. This has been reported in many other studies [24] [36].

Spontaneous bacterial peritonitis is a frequent and serious complication. It occurs in $8 \%-25 \%$ of patients hospitalized for ascites. The prognosis is much improved over the past 20 years. The rate of healing is about $80 \%$ and hospital mortality is below of 30\% [35]. This complication was found in $4.1 \%(\mathrm{~N}=45)$ of patients, and always appears as a predictor of mortality in our study.

Hepatocellular carcinoma has became the most common fatal complication of cirrhosis. In France, the mortality rate of HCC has been multiplied by 4 . This is explained primarily by the conjunction of two factors: in one hand, a decrease in mortality due to other complications of cirrhosis (like spontaneous bacterial peritonitis and bleeding due to portal hypertension) and in the other hand an increase in frequency of HCC related to cirrhosis secondary to hepatitis C [37]. In our series, this complication was not identified as a predictor of intrahospital mortality in cirrhotic patients $\mathrm{p}=0.370$ ).

Unlike other complications, there are very few studies that have focused on specific prognosis of hepatic encephalopathy, although it is a common and potentially serious complication of cirrhosis. It is estimated that the survival of cirrhotic patients after a first episode of hepatic encephalopathy, with or without other complication, is about $40 \%$ at one year and $15 \%$ to $20 \%$ in three years [37]. The short-term prognosis of cirrhotic patients admitted to intensive care unit has not been specifically studied. The difficulty of conducting this type of study is that the hepatic encephalopathy is usually associated with one or more severe complications of cirrhosis, and the prognosis is then more directly related to intercurrent complications.

In our study, hepatic encephalopathy was significantly associated with intra-hospital mortality in univariate and multivariate analysis.

Several studies have highlighted in multivariate analysis independent predictors of mortality in patients with cirrhosis: kidney failure (serum creatinine), serum bilirubin, prothrombin time, leukocytosis, cirrhosis decompensation [33] [24]. In our series, we identified in multivariate analysis four independent predictors of intra hospital mortality in patients with cirrhosis, which are hepatic encephalopathy, infection, renal failure and hyponatremia. These result joined the data of literature [24].

\section{Conclusion}

In conclusion, advanced patient age, severity of liver failure, viral origin of cirrhosis, variceal bleeding, ascites, and spontaneous bacterial peritonitis, were predictors of intra-hospital mortality in cirrhotic patients. Adding to this, hepatic encephalopathy, infection, renal failure and hyponatremia were meanwhile, independent predictors of this mortality.

\section{Conflicts of Interest}

No conflicts of interest.

\section{References}

[1] Child, C.G. and Turcotte, J.G. (1964) Surgery and Portal Hypertension. In: Child, C.G., Ed., The Liver and Portal Hypertension, Saunders, Philadelphia, 50-64.

[2] Gines, P., Quintero, E., Arroyo, V., Teres, J., Bruguera, M., Rimola, A., Caballeri, J., Rodes, J. and Rozman, C. (1987) Compensated Cirrhosis: Natural History and Prognostic Factors. Hepatology, 7, 122-128. http://dx.doi.org/10.1002/hep.1840070124

[3] Adler, M., Verset, D., Bouhdid, H., Bourgeois, B., Gulbis, B., Le Moine, O., Vanderstadt, J., Gelin, M. and Thiry, P. (1997) Prognostic Evaluation of Patients with Parenchymal Cirrhosis: Proposal of a New Simple Score. Journal of Hepatology, 26, 642-649. http://dx.doi.org/10.1016/S0168-8278(97)80431-X

[4] Merkel, C., Bolognesi, M., Bellow, S., Bianco, S., Honisen, B., Lampe, H., Angeli, P. and Gatta, A. (1992) Aminopyrine Breath Test in the Prognostic Evaluation of Patients with Cirrhosis. Gut, 33, 836-642. http://dx.doi.org/10.1136/gut.33.6.836

[5] Kamath, P.S., Wiesner, R.H., Malinchoc, M., Kremers, W., Therneau, T.M., Kosberg, C.L., D’Amico, G., Dickson, E.R. and Kim, W.R. (2001) A Model to Predict Survival in Patients with End-Stage Liver Disease. Hepatology, 33, 464-470. http://dx.doi.org/10.1053/jhep.2001.22172

[6] Orrego, H., Israel, Y., Blake, J.E. and Medline, A. (1983) Assessment of Prognostic Factors in Alcoholic Liver Disease: 
Toward a Global Quantitative Expression of Severity. Hepatology, 3, 896-905. http://dx.doi.org/10.1002/hep.1840030602

[7] Pingon, J.P., Poynard, T., Naveau, S., Marteau, P., Zourabien-Vilio, O. and Chaput, J.C. (1986) Analyse multidimensionnelle selon le modele de Cox dela survie de patients atteints de cirrhose alcoolique. Gastroentérologie Clinique et Biologique, 10, 461-467.

[8] Pugh, R.N.H., Murray-Lyon, I.M., Dawson, J.L., Pietroni, M.C. and Williams, R. (1973) Transection of the Esophagus in Bleeding Oesophageal Varices. British Journal of Surgery, 60, 648-652. http://dx.doi.org/10.1002/bjs.1800600817

[9] Teres, J., Baroni, R., Bordas, J.W., Visa, J., Pera, C. and Rodes, J. (1987) Randomized Trial of Portocaval Shunt Stapling Transection and Endoscopic Sclerotherapy in Uncontrolled Variceal Bleeding. Journal of Hepatology, 4, 159167. http://dx.doi.org/10.1016/S0168-8278(87)80075-2

[10] Rikkers, L.F., Burnett, D.A., Volentine, G.D., Buchi, K.N. and Cormier, R.A. (1987) Shunt Surgery versus Endoscopic Sclerotherapy for Longterm Treatment of Variceal Bleeding. Early Results of a Randomized Trial. Annals of Surgery, 206, 201-271. http://dx.doi.org/10.1097/00000658-198709000-00004

[11] Sauerbruch, T., Ansari, H., Wotzka, R., Soehendra, N. and Kopcke, W. (1988) Prognostic Factors in Cirrhosis of the Liver, Variceal Bleeding and Sclerotherapy: Comparison of Prognosis Systems Obtained by Discriminant Analysis with the Child-Classification. Deutsche Medizinische Wochenschrift, 113, 11-14. http://dx.doi.org/10.1055/s-2008-1067583

[12] LeMoine, O., Adler, M., Bourgeois, N., Delhayne, M., Deviere, J., Gelin, M., Vandermeeren, A., Van Gossum, A. and Vereerstraeten, P. (1992) Factors Related to Early Mortality in Cirrhotic Patients Bleeding from Varices and Treated by Urgent Sclerotherapy. Gut, 33, 1381-1385. http://dx.doi.org/10.1136/gut.33.10.1381

[13] Infante-Rivard, C., Esnaola, S. and Villeneuve, J.P. (1987) Clinical and Statistical Validity of Conventional Prognostic Factors in Predicting Short-Term Survival among Cirrhotics. Hepatolology, 7, 660-664. http://dx.doi.org/10.1002/hep.1840070408

[14] Ferro, D., Saliola, M., Quintarelli, C., Alessandri, C., Basili, S. and Violi, F. (1992) 1-Year Survey of Patients with Advanced Liver Cirrhosis: Prognostic Value of Clinical and Laboratory Indexes Identified by the Cox Regression Model. Scandinavian Journal of Gastroenterology, 27, 852-856. http://dx.doi.org/10.3109/00365529209000153

[15] Hartmann, A.H., Bircher, J. and Creutzfeldt, W. (1989) Superiority of the Child-Pugh Classification to Quantitative Liver Function Tests for Assessing Prognosis of Liver Cirrhosis. Scandinavian Journal of Gastroenterology, 24, 269276. http://dx.doi.org/10.3109/00365528909093045

[16] Zauner, C., Schneeweiss, B., Schneider, B., Madl, C., Klos, H., Kranz, A., Ratheiser, K., Kramer, L. and Lenz, K. (2000) Short-Term Prognosis in Critically Ill Patients with Liver Cirrhosis: An Evaluation of a New Scoring System. European Journal of Gastroenterology \& Hepatology, 12, 517-522. http://dx.doi.org/10.1097/00042737-200012050-00007

[17] Robert, R. and Veinstein, A. (2003) Pronostic du Malade Atteint de Cirrhose en Reanimation. Gastroentérologie Clinique et Biologique, 27, 877-881.

[18] De Franchis, R. (2005) Evolving Consensus in Portal Hypertension. Report of the Baveno IV Consensus Workshop on Methodology of Diagnosis and Therapy in Portal Hypertension. Journal of Hepatology, 43, 167-176. http://dx.doi.org/10.1016/j.jhep.2005.05.009

[19] D’Amico, G. and De Franchis, R. (2003) Upper Digestive Bleeding in Cirrhosis. Post-Therapeutic Outcome and Prognostic Indicators. Hepatology, 38, 599-612. http://dx.doi.org/10.1053/jhep.2003.50385

[20] Moitinho, E., Escorsell, A., Bandi, J.C., et al. (1999) Prognostic Value of Early Measurements of Portal Pressure in Acute Variceal Bleeding. Gastroenterology, 117, 626-631. http://dx.doi.org/10.1016/S0016-5085(99)70455-5

[21] Luca, A., Angermayr, B., et al. (2007) An Integrated MELD Model including Serum Sodium and Age Improves the Prediction of Early Mortality in Patients with Cirrhosis. Liver Transplantation, 13, 1174-1180. http://dx.doi.org/10.1002/lt.21197

[22] Londoño, M.C., Cárdenas, A., Guevara, M., et al. (2007) MELD Score and Serum Sodium in the Prediction of Survival of Patients with Cirrhosis Awaiting Liver Transplantation. Gut, 56, 1283-1290. http://dx.doi.org/10.1136/gut.2006.102764

[23] Botta, F., Giannini, E., Romagnoli, P., Fasoli, A., et al. (2003) MELD Scoring System Is Useful for Predicting Prognosis in Patients with Liver Cirrhosis and Is Correlated with Residual Liver Function: A European Study. Gut, 52, 134-139. http://dx.doi.org/10.1136/gut.52.1.134

[24] Mouelhi, L., Ben Hammouda, I., Salem, M., Moussa, A., et al. (2010) Mortalité hospitalière des patients cirrhotiques admis en milieu de soins intensifs: facteurs pronostiques et apport des scores de gravité. Journal Africain d'HépatoGastroentérologie, 4, 17-21.

[25] Calès, P. and Pascal, J.P. (1988) Histoire naturelle des varices oesophagiennes au cours de la cirrhose (de la naissance à 
la rupture). Gastroentérologie Clinique et Biologique, 12, 245-254.

[26] Carbonell, N., Pauwels, A., Serfaty, L., Fourdan, O., Lévy, V.G. and Poupon, R. (2004) Improved Survival after Variceal Bleeding in Patients with Cirrhosis over the Past Two Decades. Hepatology, 40, 652-659. http://dx.doi.org/10.1002/hep.20339

[27] De Dombal, F.T., Clarke, J.R., Clamp, S.E., Malizia, G., Kotwal, M.R. and Morgan, A.G. (1986) Prognostic Factors in Upper G.I. Bleeding. Endoscopy, 18, 6-10. http://dx.doi.org/10.1055/s-2007-1018418

[28] McCormick, P.A. and O’Keefe, C. (2001) Improving Prognosis Following a First Variceal Haemorrhage over Four Decades. Gut, 49, 682-685. http://dx.doi.org/10.1136/gut.49.5.682

[29] Levacher, S., Letoumelin, P., Pateron, D., Blaise, M., Lapandry, C. and Pourriat, J.L. (1995) Early Administration of Terlipressin plus Glyceryl Trinitrate to Control Active Upper Gastrointestinal Bleeding in Cirrhotic Patients. Lancet, 346, 865-868. http://dx.doi.org/10.1016/S0140-6736(95)92708-5

[30] Singh, N., Gayowski, T., Wagener, M.M. and Marino, I.R. (1998) Outcome of Patients with Cirrhosis Requiring Intensive Care Unit Support: Prospective Assessment of Predictors of Mortality. Journal of Gastroenterology, 33, 7379. http://dx.doi.org/10.1007/s005350050047

[31] Chalasani, N., Kahi, C., Francois, F., Pinto, A., Marathe, A., Bini, E.J., et al. (2003) Improved Patient Survival after Acute Variceal Bleeding: A Multicenter, Cohort Study. American Journal of Gastroenterology, 98, 653-659. http://dx.doi.org/10.1111/j.1572-0241.2003.07294.x

[32] Attia, K.A., Ackoundou-N'guessan, K.C., N’dri-yoman, A.T., et al. (2008) Child-Pugh-Turcott versus Meld Score for Predicting Survival in a Retrospective Cohort of Black African Cirrhotic Patients. World Journal of Gastroenterology, 14, 286-291. http://dx.doi.org/10.3748/wig.14.286

[33] Bernard, B., Grangé, J.D., Nguyen Khac, E., Amiot, X., Opolon, P. and Poynard, T. (1999) Antibiotic Prophylaxis for the Prevention of Bacterial Infections in Cirrhotic Patients with Gastrointestinal Bleeding: A Metaanalysis. Hepatology, 29, 1655-1661. http://dx.doi.org/10.1002/hep.510290608

[34] (2004) Conférence de consensus: Complications de l’hypertension portale. Gastroenterology, 28, B324-B334.

[35] Karoui, S., Hamzaoui, S., Sahli, F., et al. (2002) Mortalité au cours des cirrhoses: Prévalence, causes et facteurs prédictifs. Tunisie Médicale, 80, 21-25.

[36] Trinchet, J.C. (2002) Histoire naturelle de l'infection par le virus de l'hépatite C. Gastroentérologie Clinique et Biologique, 26, B144-B153.

[37] Bustamante, J., Rimola, A., Ventura, P.J., Navasa, M., Cirera, I., Reggiardo, V., et al. (1999) Prognostic Significance of Hepatic Encephalopathy in Patients with Cirrhosis. Journal of Hepatology, 30, 890-895. http://dx.doi.org/10.1016/S0168-8278(99)80144-5 